\title{
Third-Generation Biofuels: An Alternate Strategy
}

\author{
Sonam Antil* \\ College of Basic Sciences and Humanities, CCS HAU, Hisar, Haryana 125004, India \\ *Corresponding author
}

\section{Keywords}

Fossil fuels,

Biofuels,

Microalgae, Lipid

\section{Article Info}

Accepted:

07 October 2019

Available Online:

10 November 2019

\section{A B S T R A C T}

Rapid industrialization and high population growth are two major reasons contributing to the global energy crisis. Today, almost $88 \%$ of worldwide energy consumption is a consequence of the combustion of fossil fuels. Biofuel production from renewable energy sources is largely considered as one of the most sustainable strategies to shift from petroleum based fuels and a considerable means for environmental and economic sustainability. Microalgae are recently being regarded as an ideal third-generation biofuel feedstock because of their fast growth rate, the high lipid production ability and capacity to fix $\mathrm{CO}_{2}$. These also do interfere with food or feed crops and can be grown on non-agricultural land. In this review, the use of microalgae for biodiesel and bioethanol production, including their cultivation, harvesting, and processing to yield biofuels will be discussed.

\section{Introduction}

Biofuels are solid, liquid or gaseous fuels derived from organic matter. The major issues like the depletion of fossil fuels, energy security, increasing petroleum prices, and global warming are paving a way to growing worldwide interests in renewable energy sources such as biofuels. Biofuels have energy that is stabilized through the process of biological carbon fixation, in which carbon dioxide $\left(\mathrm{CO}_{2}\right)$ is converted into glucose that is only present in living organisms such as plants. In comparison to fossil fuels, biofuel is produced by living organisms in a relatively short duration of time instead of being derived by the decomposition of organic matter over several million years (Alaswad et al., 2015).

Till recent times, the waste products of food were considered as the feedstock for biofuel production.

Recently, the emphasis is on various highly productive organisms to yiels biofuel and the likelihood of microalgae as the next generation of biofuel feedstock. At present, microalgae are being considered as a perfect 
feedstock for third-generation biofuel due to their fast growth capacity, reduction in greenhouse gas emission, and high lipid (oil) production rate

\section{Types of biofuels}

Biofuels are normally classified into two classes: primary and secondary biofuels. Primary biofuels mainly consist of fuel wood which is used in an unprocessed form majorily for heating, cooking or electricity production while secondary biofuels are bioethanol and biodiesel which are obtained by processing biomass that are used in vehicles and various industrial processes. The second type of biofuels further categorized into three generations based on different parameters like, processing technology type, nature of feedstock or development levels (Nigam et al., 2010).Although biofuel have a great potential to provide an alternative to fossil fuels, firstgeneration production systems have high environmental and economy related limitations while the main problem with second-generation biofuels is converting the complex lignocellulosic biomass into fermentable sugars which requires costly pretreatment techniques.

Therefore, third generation feedstock or microalgae based biofules are considered to be a productive alternative energy resource that is free of the major drawbacks associated with first and second-generation biofuels (Chisti, 2007; Li et al., 2008, Schenk et al., 2008; Brennan and Owende, 2010).

\section{Importance of Microalgae}

The thought of using microalgal feedstock is not a new one. The continuous depletion of natural fuels and rising petroleum prices are the main reasons that the focus has been put on microalgal based fuels. The utilization of microalgaeal feedstock for producing biofuels has many advantages when compared to higher plants. Microalgae naturally synthesize and concentrate large quantities of neutral oils (20-50\% dry weight of biomass) and has a high growth rate. There is whole year production, hence more oil yield.

Also microalgae need less water, do not require herbicides or pesticides application, reduce emissions of a major greenhouse $\left(\mathrm{CO}_{2}\right)$. These can tolerate harsh conditions for growth and have reduced need for nutrients (Um and Kim, 2009; Mata et al., 2010).

\section{Microalgae cultivation system}

A microalgal cultivation system must have properties like high area productivity, high volumetric productivity, economical feasibility (both in terms of investment and maintenance costs, easy control conditions (temperature, $\mathrm{pH}, \quad \mathrm{O}_{2}, \quad$ turbulence) and dependability for commercial scale production.

Different types of microalgal cultivation systems try to accomplish these characteristics in their own ways. Photobioreactors are basically used for microalgae cultivation. Despite the term photobioreactor (PBR) is enforced to open ponds and channels, scientists have differentiated between open-air systems and PBRs (preferably monoseptic cultures) (Dragone et al., 2010).

\section{Harvesting Methods}

Harvesting of microalgal biomass can be done by several physical, chemical or biological ways like Flocculation (which is an initial dewatering step in the bulk harvesting process for enhancing the ease of further processing),Centrifugation (in which centrifugal forces are used to separate microalgal biomass from the medium), flotation, filteration, etc. 


\section{Microalgal lipid extraction}

This includes various steps like Biomass drying (spray drying, drum drying, freezedrying, fluidized bed drying and reflectance window dehydration technique), Cell disruption (autoclaving, high-pressure homogenisers, and addition of strong acids and bases like hydrochloric acid, sulphuric acid, sodium hydroxide, or alkaline lysis) and Lipid extraction (solvent extraction, expeller/oil press,, supercritical fluid extraction (SFE) and ultrasound techniques)(Brennan an Owende, 2010; Harun et al., 2010)After extracting oil from microalgal biomass, it can be converted into bioethanol and biodiesel.

\section{Challenges faced while using microalgae}

When microalgae is used as feedstock for biofuel generation, many challenges comeinto way like technical issues with the fuel flow, huge amount of land is required for growing microalgae, high production cost and unknown retail price. Further research is needed in this field for commercial application for microalgal feedstock.

\section{Future perspective}

Microalgae acts as sustainablethird generation feedstock for the production of biofuels like biodiesel and bioethanol. However, there are several considerable scientific and technical barriers need to be overcome before the commercial scale production of microalgae derived biofuels.

Development of technologies like advances in designing of photobioreactor(PBR), harvesting, drying, and processing of microalgal biomass to yield biofuels are important areas that need to be researched which may lead to increased costeffectiveness and hence, effective application of the biofuel from microalgae strategy on a commercial scale.

\section{References}

Alaswad A, Dassisti M, Prescott T, Olabi AG. Technologies and developments of third generation biofuel production. Renew Sustain Energy Rev, 2015; 51: 1446-60.

Brennan L, Owende P. Biofuels from microalgae--A review of technologies for production, processing, and extractions of biofuels and coproducts. Renewable and Sustainable Energy Reviews. 2010; 14: 557-577.

Chisti Y. Biodiesel from microalgae. Biotechnology Advances. 2007; 25: 294-306.

Dragone, G., Fernandes, B.,Vicente, A.A \&Teixeira, J.A. Third generation biofuels from microalgae. Current Research, Technology and Education Topics in Applied Microbiology and Microbial Biotechnology.2010.

Harun R, Singh M, Forde GM, Danquah MK. Bioprocess engineering of microalgae to produce a variety of consumer products. Renewable and Sustainable Energy Reviews. 2010; 14:1037-1047.

Li Y, Horsman M, Wu N, Lan CQ, DuboisCalero N. Biofuels from microalgae. Biotechnology Progress. 2008; 24:815820.

Mata TM, Martins AA, Caetano NS. Microalgae for biodiesel production and other applications: A review. Renewable and Sustainable Energy Reviews. 2010; 14:217-232.

Nigam PS, Singh A. Production of liquid biofuels from renewable resources. Progress in Energy and Combustion Science. 2010; In press.

Schenk P, Thomas-Hall S, Stephens E, Marx U, Mussgnug J, Posten C, Kruse O, Hankamer B. Second generation 
biofuels: high efficiency microalgae for biodiesel production. BioEnergy Research. 2008; 1:20-43.
Korea to advance algal-biodiesel technology. Journal of Industrial and Engineering Chemistry. 2009; 15:1-7.

Um B-H, Kim Y-S. Review: A chance for

\section{How to cite this article:}

Sonam Antil. 2019. Third-Generation Biofuels: An Alternate Strategy. Int.J.Curr.Microbiol.App.Sci. 8(11): 585-588. doi: https://doi.org/10.20546/ijcmas.2019.811.071 